\title{
PENGARUH EKSTRAK ETANOL DAUN KEREHAU (Callicarpa longifolia Lamk.) PADA KADAR MALONDIALDEHID HEWAN YANG DIINDUKSI ALOKSAN
}

\section{EFFECT OF ETHANOL EXTRACT OF KEREHAU LEAVES (Callicarpa longifolia Lamk.) ON MALONDIALDEHYDE LEVELS OF ANIMALS INDUCED BY ALLOXAN}

\author{
Elis Susilawati ${ }^{{ }^{*}}$, Idar Idar ${ }^{2}$, Meiadi Putra Utama Aritonang ${ }^{3}$ \\ ${ }^{1,2,3}$ Fakultas Farmasi Universitas Bhakti Kencana Bandung, Indonesia \\ email: ${ }^{*}$ elis.susilawati@stfb.ac.id, ${ }^{2}$ idar.icemetz@abc.ac.id, ${ }^{3}$ pmeiadi@ymail.com
}

\begin{abstract}
ABSTRAK
Kerehau (Callicarpa longifolia Lamk.) memiliki aktivitas antioksidan. Salah satu fungsi antioksidan adalah untuk menurunkan stress oksidatif. Stress oksidatif ini dialami sel pada kondisi dimana jumlah radikal bebas melebihi kapasitas (contohnya pada kondisi diabetes mellitus) yang ditandai dengan adanya kadar malondialdehid diatas normal. Antioksidan dapat menurunkan stress oksidatif pada diabetes mellitus dan menurunkan kadar glukosa darah. Penelitian ini bertujuan untuk mengetahui bagaimana efek antidiabetes ekstrak etanol daun kerehau dalam mempengaruhi kadar malondialdehid. Metode yang digunakan adalah defisiensi insulin menggunakan mencit Swiss Webster yang dikelompokkan menjadi 6 kelompok yaitu kontrol negatif, kontrol positif, kontrol pembanding (glibenklamid 0,65 mg/KgBB), dosis uji I (75 $\mathrm{mg} / \mathrm{KgBB}$ ), dosis uji II (150 mg/KgBB), dan dosis uji III (300 mg/KgBB). Pada metode defisiensi insulin diinduksi dengan aloksan dosis $55-60 \mathrm{mg} / \mathrm{KgBB}$. Pemberian ekstrak etanol daun kerehau diberikan selama 14 hari. Selama pemberian terapi, kadar gula darah diukur pada hari ke-7, 11 dan 14. Setelah itu mencit diambil darah nya lewat vena ekor dan dilakukan pengukuran kadar malondialdehid menggunakan spektrofotometer. Hasilnya semua dosis uji dapat menurunkan kadar gula darah pada hari ke-7 dan mempengaruhi kadar malondialdehid karena terdapat perbedaan bermakna dengan mencit yang tidak diberi terapi. Kesimpulannya yaitu ekstrak etanol daun kerehau dapat mempengaruhi kadar malondialdehid.
\end{abstract}

Kata Kunci : antidiabetes, defisiensi insulin, kerehau, malondialdehid

\begin{abstract}
Kerehau (Callicarpa longifolia Lamk.) has antioxidant activity. One function of antioxidants is to reduce oxidative stress. This oxidative stress is experienced by cells in conditions where the total of free radicals exceeds capacity (for example in the condition of diabetes mellitus) which is characterized by the presence of malondialdehyde levels above normal. Antioxidants can reduce oxidative stress in diabetes mellitus and reduce blood glucose levels. This research aims to know how the antidiabetic effects of ethanol extract of the leaves of Kerehau in affecting malondialdehyde levels. The method used was insulin deficiency using Swiss Webster mice grouped into 6 groups namely negative control, positive control, comparative control (glibenclamide $0.65 \mathrm{mg} / \mathrm{KgBB}$ ), test dose I ( $75 \mathrm{mg} / \mathrm{KgBB})$, test dose II (150 mg/KgBB), and test dose III (300 mg/KgBB). In the method of insulin deficiency induced with alloxan a dose of 55 $60 \mathrm{mg} / \mathrm{KgBB}$. Giving ethanol extract of Kerehau leaves was given for 14 days. During given of therapy, blood glucose levels were measured on days 7,11 and 14. After that, the mice were taken blood through the tail vein and measured the levels of malondialdehyde using a spectrophotometer. The result is that all test doses can reduce blood sugar levels on day 7 and
\end{abstract}


affect malondialdehyde levels because there are significant differences with mice that are not given therapy. The conclusion is, the ethanol extract of kerehau leaves can affect the levels of malondialdehyde..

\section{Keywords: antidiabetic, insulin deficiency, kerehau, malondialdehyde}

\section{PENDAHULUAN}

Malondialdehid merupakan salah satu penanda radikal bebas pada tubuh. Malondialdehid (MDA) dihasilkan dari peroksidasi lipid pada membran sel, dimana terdapat reaksi antara radikal bebas dengan Poly Unsaturated Fatty Acid (PUFA) sehingga tingkat peroksidasi lipid dapat diperkirakan dengan melihat jumlah Malondialdehid pada jaringan (Sirait, 2016). Berbagai komplikasi dapat terjadi akibat tingginya stress oksidatif, salah satunya diabetes melitus. Prevalensi diabetes mellitus di dunia, 422 juta orang dewasa berusia di atas 18 tahun menderita diabetes pada tahun 2014, tahun 2017 terdapat 425 juta orang dewasa menderita diabetes, dan diperkirakan pada tahun 2045 akan mencapai 629 juta orang dewasa yang menderita diabetes.

Jumlah orang dengan tingkat pertumbuhan antara tahun 1980 dan 2014 meningkat dari 108 juta menjadi empat kali lebih tinggi. Prevalensi diabetes global telah tumbuh dari $4,7 \%$ pada tahun 1980 menjadi $8,5 \%$ pada tahun 2014, dimana keadaan diabetes meningkat setiap tahun nya di setiap negara. Indonesia sendiri menduduki peringkat 6 dari 10 negara dengan jumlah orang dewasa penderita diabetes tertinggi di dunia (International Diabetes Federation, 2017) (Roglic dan World Health Organization 2016).

Salah satu penyebab terjadinya diabetes dapat disebabkan oleh stress oksidatif, dimana terjadi peningkatan produksi radikal bebas atau spesies oksigen reaktif (ROS) yang dapat merusak jaringan. Bersama lipid, ROS dapat mengoksidasi lipid tersebut menjadi MDA (malondialdehid) sehingga MDA dapat menjadi biomarker terjadinya stress oksidatif.

Pada pasien DM terjadi gangguan metabolisme lemak yang dapat meningkatkan resiko terjadinya pembentukan MDA oleh ROS, sehingga aloksan yang berperan sebagai meningkatkan radikal bebas dapat memicu stress oksidatif. Pengobatan diabetes pada umumnya masih banyak efek samping yang dimiliki khususnya untuk penggunaan jangka panjang seperti nyeri otot, lemas, dan sulit bernafas. Oleh karena itu diperlukan pengobatan alternatif yang mampu menurunkan glukosa darah pada penderita diabetes dengan efek samping yang lebih minim (Tiwari. 2013).

Salah satu tanaman yang diduga dapat mengurangi stress oksidatif adalah tanaman yang berasal dari Kalimantan dan digunakan oleh suku Dayak Tanjung dimanfaatkan sebagai obat tradisional, yaitu Kerehau (Callicarpa longifolia Lamk.). Aktivitas tumbuhan kerehau sudah dibuktikan secara ilmiah yaitu sebagai antiinflamasi, analgetik, penyembuhan luka, dan antidiabetes. Pada penelitian sebelumnya daun Kerehau terbukti memiliki aktivitas antidiabetes pada model hewan resistensi insulin yang diinduksi emulsi lemak dan defisiensi insulin relatif yang diinduksi Aloksan. (Susilawati dkk. 2018)

Daun kerehau (Callicarpa longifolia .Lamk) memiliki aktivitas yang baik sebagai antiinflamasi karena mampu memperbaiki jaringan yang rusak sehingga dapat memperbaiki diameter luka pada kaki tikus putih. Daun Kerehau (Callicarpa Iongifolia .Lamk) memiliki senyawa metabolit sekunder seperti tannin, saponin dan flavonoid. (Semiawan, Ahmad, dan Masruhim 2015). Sementara flavonoid memiliki khasiat untuk mengurangi peradangan pada luka, oleh karena itu daun Kerehau dapat digunakan sebagai anti-inflamasi. Flavonoid juga memiliki khasiat sebagai antioksidan dan dapat meningkatkan sekresi insulin melalui regenerasi sel $\beta$ pankreas (Susilawati dkk, 2018).

Berdasarkan latar belakang diatas, penelitian ini bermaksud untuk mengembangkan aktivitas daun Kerehau pada model hewan yang mengalami stress oksidatif yang diukur 
melalui parameter radikal bebas. Maka dari itu perlu dikembangkan kembali potensi daun kerehau sebagai antidiabetes.

\section{METODE}

Prosedur Penelitian. daun Kerehau (Callicarpa longifolia .Lamk) didapatkan dari Desa Tumbang Lahang, Kabupaten Katingan, Kalimantan Tengah, dan dideterminasi di Universitas Lambung Mangkurat, Kalimantan (No :010b/LB.LABDASAR/I/2019).

Hewan Percobaan : Penelitian ini menggunakan hewan uji Mencit jantan galur Swiss Webster dengan bobot 20-30 gram. Penggunaannya hewan percobaan telah disetujui oleh Komisi Etik Penelitian Universitas Padjadjaran Bandung yang tertulis pada surat Persetujuan Etik Nomor: 446/UN6.KEP/EC/2019

Karakteriasi simplisia: karakterisasi dilakukan pada serbuk daun kerehau yang meliputi kadar air, kadar abu total, kadar abu tak larut asam, kadar sari larut air, kadar sari larut ethanol dan susut pengeringan.

Skrining fitokimia: skrining fitokimina dilakukan pada ekstrak ethanol daun kerehau yang meliputi identifikasi alkaloid, saponin, tannin, terpenoid, dan flavonoid.

Ekstraksi: dilakukan dengan metode maserasi menggunakan pelarut etanol 96\% dengan perbandingan 1:5. Ekstrak cair yang diperoleh kemudian diepekatkan menggunakan rotary evaporator.

Defisiensi insulin: Metode ini dilakukan secara kuratif menggunakan hewan uji mencit Swiss Webster. Model hewan resistensi insulin dibentuk menggunakan induksi Aloksan $55-60 \mathrm{mg} / \mathrm{KgBB}$ secara oral selama 14 hari dengan parameter yang diamati adalah nilai kadar gula darah. Mencit yang telah diaklimatisasi dipuasakan terlebih dahulu selama 6-8 jam lalu diukur kadar glukosa darah awal lalu dibagi menjadi 6 kelompok yaitu kelompok kontrol positif, kelompok kontrol negatif, kelompok Glibenklamid 65mg/KgBB, EEDK (ekstrak ethanol daun kerehau) $75 \mathrm{mg} / \mathrm{kgBB}$, EEDK $150 \mathrm{mg} / \mathrm{kgBB}$ dan EEDK $300 \mathrm{mg} / \mathrm{kgBB}$.

Setelah itu mencit diinduksi Aloksan pada semua kelompok kecuali kelompok negatif (-). Setelah 3 hari induksi dilakukan pemberian terapi selama 14 hari secara per oral. Pada hari ke $3\left(\mathrm{t}_{0}\right), 7\left(\mathrm{t}_{7}\right)$, dan $14\left(\mathrm{t}_{14}\right)$. Parameter pengamatan yang dilakukan adalah pengukuran kadar glukosa darah pada hari ke 3( $\left.\mathrm{t}_{0}\right), 7\left(\mathrm{t}_{7}\right)$, dan $14\left(\mathrm{t}_{14}\right)$ kemudian histologi dan pengukuran kadar MDA. (Susilawati, dkk 2017).

Pengukuran Kadar Malondialdehid: Selain itu mencit dilakukan pengambilan darah melalui jantung. Darah dimasukkan ke dalam mikrotube dan didiamkan pada suhu $\pm 4{ }^{\circ} \mathrm{C}$ selama beberapa saat hingga terbentuk dua bagian, yaitu serum dan bekuan (clot) unsur seluler darah. Selanjutnya, sampel darah disentrifugasi pada kecepatan 3000 rpm selama 10 menit. Serum dipisahkan ke dalam mikrotube bersih untuk diuji kadar MDA-nya.

Pengukuran kadar MDA serum dilakukan dengan thiobarbituric acid reactive substance (TBARS) assay. Sampel serum darah mencit dipipet sebanyak $100 \mu \mathrm{l}$ ke dalam mikrotube, ditambahkan 0,5 ml larutan TCA 20\% dan 1 ml larutan TBA 0,67\%, lalu dihomogenkan. Larutan yang telah homogen dipanaskan dalam water bath pada suhu $95^{\circ} \mathrm{C}$ selama 15 menit, kemudian didinginkan pada suhu ruang. Setelah itu, larutan disentrifugasi pada kecepatan 3000 rpm selama 10 menit. Supernatan yang berwarna merah muda diukur absorbansinya menggunakan spektrofotometer pada panjang gelombang $532 \mathrm{~nm}$. Hasil pembacaan absorbansi dicocokkan dengan kurva standar MDA (Kurniasari, Yanti, dan Setyawati 2017).

Data hasil glukosa darah yang diperoleh dianalisis secara statistic menggunakan metode one way anova untuk melihat apakah dosis ekstrak yang diberikan memiliki pengaruh terhadap penurunan kadar glukosa darah yang dibandingkan terhadap kelompok kontrol.

\section{HASIL DAN PEMBAHASAN}




\section{Karakterisasi Simplisia}

Hasil karakteristik simplisia merupakan standarisasi untuk mengetahui mutu dan kualitas yang dikandung simplisia. Berdasarkan hasil karakteristik (Tabel 1), daun kerehau memiliki kadar air lebih kecil dari 10\%. Dengan hasil ini dapat ditetapkan bahwa kadar air kerehau memenuhi syarat yang sudah ditetapkan pada Materia Medika Indonesia edisi IV.

Air merupakan media pertumbuhan bagi mikroorganisme dan media terjadinya reaksi enzimatis yang dapat menguraikan senyawa aktifnya. Maka dari itu kadar air pada simplisia haruslah rendah agar menjaga kualitas dan khasiat dari simplisia itu sendiri. Sementara hasil kadar abu total sebesar $6,75 \%$ dan kadar abu tak larut asam sebesar $0,75 \%$. Dilakukan nya penetapan kadar abu bertujuan untuk menunjukkan kadar senyawa organic dalam simplisia seperti logam $\mathrm{K}, \mathrm{Ca}$, $\mathrm{Na}, \mathrm{Pb}, \mathrm{Hg}$, dan silika. Simplisia ini juga mempunyai kadar sari larut air sebesar 15,2\% dan sari larut etanol sebesar $17,92 \%$. Penetapan kadar sari larut air bertujuan untuk mengetahui kandungan senyawa polar dalam simplisia, sedangkan penetapan kadar sari larut etanol betujuan untuk mengetahui kandungan senyawa polar dan nonpolar yang larut dalam pelarut polar. Dan dilihat dari nilai susut pengeringan nya didapatkan hasil sebesar $8.19 \%$.

Tabel 1. Krakteristik Simplisia Daun Kerehau

\begin{tabular}{lcc}
\hline Karakteristik Simplisia & Hasil & $\begin{array}{c}\text { Penelitian sebelumnya } \\
\text { (Supomo dkk, 2015) }\end{array}$ \\
\hline Kadar Air & $8,89 \%$ & $9,6 \%$ \\
Kadar Abu Total & $6,75 \%$ & $6 \%$ \\
Kadar Abu Tak Larut & $0,675 \%$ & $1 \%$ \\
Asam & & \\
Kadar Sari Larut Air & $15,2 \%$ & $17,7 \%$ \\
Kadar Sari Larut & 17,92 & $11,3 \%$ \\
Etanol & $\%$ & \\
Susut Pengeringan & $8,19 \%$ & - \\
\hline
\end{tabular}

\section{Skrining Fitokimia}

Skrining fitokimia dilakukan terhadap serbuk dan ekstrak daun kerehau (Callicarpa longifolia Lamk.) dan diperoleh hasil sebagai berikut:

\section{Tabel 2. Skrining Fitokimia Ekstrak} Ethanol Daun Kerehau

\begin{tabular}{lcc}
\hline \multicolumn{1}{c}{ Uji Senyawa } & Hasil & $\begin{array}{r}\text { Penelitian sebelumnya } \\
\text { (Supomo dkk, 2015) }\end{array}$ \\
\hline Alkaloid & $(-)$ & $(-)$ \\
Flavonoid & $(+)$ & $(+)$ \\
Tanin & $(+)$ & $(+)$ \\
Saponin & $(+)$ & $(+)$ \\
Kuinon & $(+)$ & $(+)$ \\
Steroid/Terpenoid & $(+)$ & $(+)$ \\
\hline
\end{tabular}

Keterangan:

+ : mengandung senyaa metabolit sekunder - : tidak mengandung senyaa metabolit sekunder

\section{Defisiensi Insulin}

Pengujian ini dilakukan secara kuratif dimana hewan uji diinduksi terlebih dahulu lalu dilakukan pengobatan. Obat pembanding yang digunakan yaitu Glibenklamid dengan mekanismenya meningkatkan pelepasan insulin dari pankreas. Pada metode ini, model hewan defisiensi insulin disrusak sel $\beta$ pankreasnya terlebih dahulu menggunakan aloksan dengan dosis $55-60 \mathrm{mg} / \mathrm{KgBB}$. Pemberian aloksan dilakukan secara intravena pada ekor mencit berlaku untuk semua kelompok kecuali kelompok control negatif (-). Setelah 3 hari diinduksi aloksan, cek kadar gula darah puasa pada mencit menggunakan alat glukometer Easy Touch $\AA$. Hewan yang digunakan untuk dilakukan penelitian yaitu hewan dengan hasil kadar glukosa darahnya mencapai $\geq 200 \mathrm{mg} / \mathrm{dl}$ (t0). Hewan uji yang akan dilakukan penelitian terbagi menjadi beberapa kelompok yaitu kelompok I sebagai kontrol negatif, kelompok II sebagai kontrol positif, kelompok III sebagai pembanding dengan menggunakan glibenklamid $0,65 \mathrm{mg} / \mathrm{KgBB}$, kelompok IV dosis $75 \mathrm{mg} / \mathrm{KgBB}$ ekstrak etanol daun kerehau, kelompok $\mathrm{V}$ dosis $150 \mathrm{mg} / \mathrm{KgBB}$ ekstrak etanol daun kerehau, dan kelompok $\mathrm{VI}$ dosis $300 \mathrm{mg} / \mathrm{KgBB}$ ekstrak etanol daun kerehau.Untuk pengobatan nya diberikan selama 14 hari secara peroral. Selama dilakukan pemberian terapi akan dilakukan pengecekan kadar glukosa darah puasa pada hari ke 3(t0), 7(t7), 11(t11), dan 14(t14). Pengambilan darah dilakukan dengan menusuk aliran darah vena dengan menggunakan lanset pada ekor mencit. 
Volume darah yang diperoleh dari mencit kurang lebih 1-3 tetes lalu diteteskan pada strip test glukosa yang kemudian akan diukur dengan menggunakan alat glukometer Easy Touch®.

Tabel 3. Rata-rata Nilai Kadar Glukosa Darah Tiap Kelompok

\begin{tabular}{|c|c|c|c|c|c|}
\hline \multirow{2}{*}{ Kelompok } & \multicolumn{4}{|c|}{ Kadar Glukosa Darah } & \multirow{2}{*}{$\begin{array}{c}\% \\
\text { Penuruna } \\
n\end{array}$} \\
\hline & T0 & $\mathrm{T7}$ & T11 & T14 & \\
\hline Kontrol Negatif & $86,80 \pm 6.1^{*} \#$ & $81,4 \pm 4,9^{*}$ & $80 \pm 17,1^{*}$ & $100 \pm 13,1^{*}$ & $-15,2 \%$ \\
\hline Kontrol Positif & $352,2 \pm 81,3$ & $367 \pm 122,6 \#$ & $351 \pm 131,4 \#$ & $366,6 \pm 134,3 \#$ & $-4,1 \%$ \\
\hline $\begin{array}{l}\text { Glibenklamid } 65 \\
\mathrm{mg} / \mathrm{KgBB}\end{array}$ & $375,6 \pm 35,4$ & $225,6 \pm 98,7^{\star}$ & $158,6 \pm 91,8^{*}$ & $139 \pm 80,8^{*}$ & $63,0 \%$ \\
\hline $\begin{array}{l}\text { EEDK } 75 \\
\mathrm{mg} / \mathrm{KgBB}\end{array}$ & $369,8 \pm 36,0$ & $324 \pm 23,8$ & $262,4 \pm 36,9 \#$ & $169,8 \pm 55,9^{*}$ & $54,1 \%$ \\
\hline $\begin{array}{l}\text { EEDK } 150 \\
\mathrm{mg} / \mathrm{KgBB}\end{array}$ & $362,2 \pm 84,1$ & $225,2 \pm 101,8^{*}$ & $136 \pm 63,9^{*}$ & $93,4 \pm 32,8^{*}$ & $74,2 \%$ \\
\hline $\begin{array}{l}\text { EEDK } 300 \\
\mathrm{mg} / \mathrm{KgBB}\end{array}$ & $364,4 \pm 76,5$ & $149,8 \pm 109,4^{*}$ & $94,42 \pm 23,0^{*}$ & $83,2 \pm 23,5^{*}$ & $77,2 \%$ \\
\hline
\end{tabular}

\section{Keterangan:}

* = Berbeda bermakna $(p<0,05)$ terhadap kontrol positif, \# = Berbeda bermakna $(p<0,05)$ terhadap glibenklamid 0,65 mg/Kg BB, EEDK = Ekstrak Etanol Daun Kerehau

Data diatas menunjukkan hasil dari pengujian antidiabetes metode defisiensi insulin. Terdapat data penurunan kadar glukosa darah yang cukup bervariasi dan juga memperoleh standar deviasi yang cukup besar. Setelah dilakukan pengolahan data dengan menggunakan meetode one way anova, terlihat dari hasil statistiknya bahwa pada hari ketiga $(\mathrm{H} 0)$ setelah diinduksi hingga hari ke-14 (H14) kelompok kontrol negatif memilik perbedaan bermakna $(p<0,05)$ terhadap kelompok kontrol positif. Demikian juga pada kelompok pembanding dengan kelompok uji, terdapat kenaikan kadar glukosa darah pada hari ketiga setelah diinduksi $(\mathrm{H} 0)$. Disini menunjukkan bahwa aloksan efektif dalam membuat model mencit yang diabetes. Mekanisme aloksan yaitu dapat merusak pankreas secara parsial sehingga pankreas masih dapat memproduksi insulin. Aloksan selektif menghambat sekresi insulin yang diinduksi glukosa melalui penghambatan glukokinase spesifik, sensor glukosa pada sel beta yang dapat menyebabkan keadaan diabetes yang bergantung pada insulin melalui kemampuannya untuk menginduksi pembentukan spesies oksigen reaktif (ROS), yang menghasilkan nekrosis selektif pada sel beta (Lenzen, 2008).

Setelah itu data diatas juga menunjukkan bahwa terdapat perbedaan bermakna dari kelompok kontrol negatif terhadap kelompok pembanding yang diberi terapi glibenklamid $0,65 \mathrm{mg} / \mathrm{KgBB}$. Hal ini menunjukkan bahwa metode defisiensi insulin berhasil sehingga ada perbedaan yang signifikan antara kedua kelompok tersebut. Mekanisme dari glibenklamid yaitu merangsang sekresi insulin pada sel $\beta$ pankreas yang masih bisa berfungsi memproduksi insulin (Dipiro, 2014) sehingga adanya penurunan kadar glukosa darah pada kelompok pembanding glibenklamid dosis $0,65 \mathrm{mg} / \mathrm{KgBB}$ (Dipiro, 2014).

Pada ketiga kelompok dosis uji, yaitu ekstrak etanol daun kerehau $75 \mathrm{mg} / \mathrm{KgBB}, 150$ $\mathrm{mg} / \mathrm{KgBB}, 300 \mathrm{mg} / \mathrm{KgBB}$ jika dilihat dari Gambar 6.2 menunjukkan bahwa kelompok dosis uji dapat menurunkan kadar glukosa darah secara signifikan hingga hari ke-14 $(\mathrm{H} 14)$ dan jika dilihat dari hasil statistik memiliki perbedaan bermakna $(<0,05)$ terhadap kelompok kontrol positif. Demikian 
juga pada kolom persentase penurunan, data kadar glukosa darah dari kelompok kontrol negatif dan positif mengalami kenaikan masing masing $15,2 \%$ dan $4,1 \%$. Kemudian, kelompok pembanding memiliki persentase penurunan yang cukup besar yaitu $63 \%$. Sedangkan data persen penurunan kadar glukosa darah pada kelompok ekstrak etanol daun kerehau dengan dosis $75 \mathrm{mg} / \mathrm{KgBB}$, $150 \mathrm{mg} / \mathrm{KgBB}$, dan $300 \mathrm{mg} / \mathrm{KgBB}$ mengalami penurunan kadar glukosa darah masing masing sebesar $54,1 \%, 74,2 \%$, dan $77,2 \%$. Disini terlihat jelas bahwa kelompok ekstrak etanol daun kerehau dengan dosis uji 150 dan $300 \mathrm{mg} / \mathrm{KgBB}$ memperoleh persentase yang sangat tinggi dibandingkan dengan kelompok dosis uji yang lainnya. Sehingga dosis uji 150 dan $300 \mathrm{mg} / \mathrm{KgBB}$ dapat menurunkan kadar glukosa darah yang paling besar dibandingkan dengan dosis 75 $\mathrm{mg} / \mathrm{KgBB}$. Maka dari itu dengan memperoleh persentase yang terlalu besar dinyatakan menimbulkan hipoglikemia, maka dari itu dapat disimpulkan dosis uji yang paling efektif menurunkan kadar gula darah adalah pada dosis $75 \mathrm{mg} / \mathrm{KgBB}$. Penurunan kadar glukosa darah terjadi karna diduga adanya perbaikan pankreas sel $\beta$ yang dapat memproduksi insulin. Ekstrak etanol daun kerehau memiliki senyawa metabolit sekunder yaitu flavonoid. Pada penelitian sebelumnya flavonoid memiliki aktivitas antioksidan yang dapat melindungi tubuh dari kerusakan yang disebabkan oleh spesies oksigen reaktif. Flavonoid juga mampu mengatasi defisiensi insulin karna dapat meregenerasi sel-sel $\beta$ pankreas (Marianne, 2014).

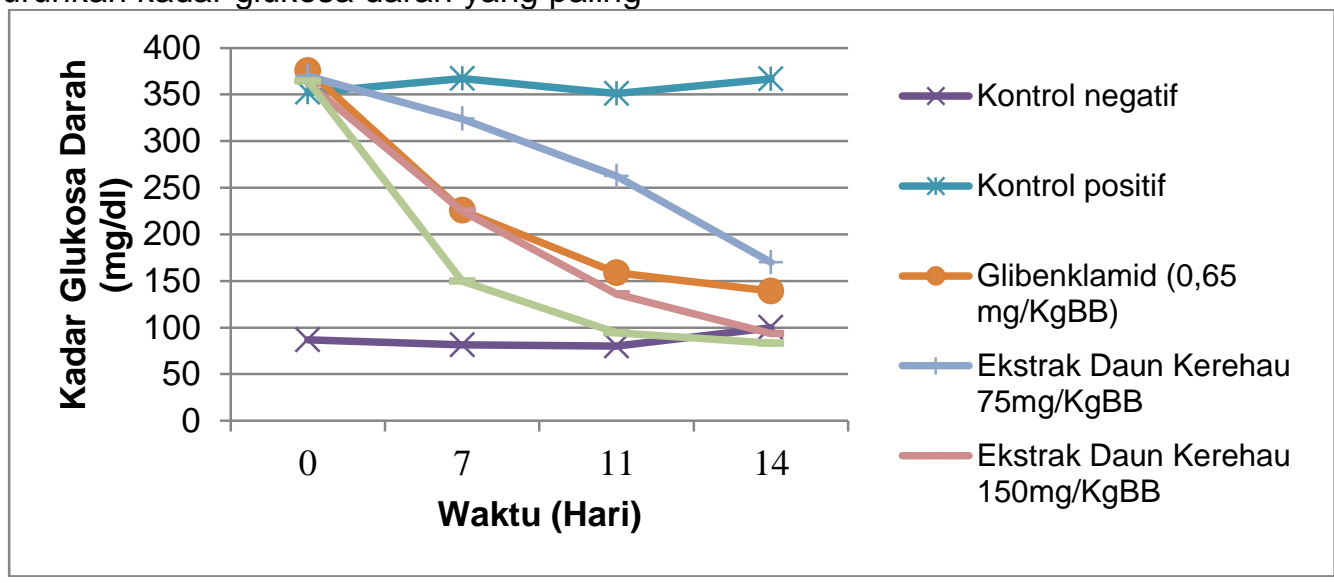

Gambar 1. Rata-Rata Kadar Glukosa Darah Tiap Kelompok

Tabel 4. Kadar MDA Pada Mencit Pengukuran Kadar Malondialdehid

\begin{tabular}{cc}
\hline Kelompok Perlakuan & Kadar MDA $(\mathrm{nmol} / \mathrm{mL})$ \\
\hline Kontrol Negatif & $45,38 \pm 8,54^{*}$ \\
Kontrol Positif & $84,38 \pm 10,31$ \\
Glibenklamid 0,65 mg/KgBB & $54,38 \pm 15,03^{\star}$ \\
EEDK $75 \mathrm{mg} / \mathrm{KgBB}$ & $63,78 \pm 7,10$ \\
EEDK $150 \mathrm{mg} / \mathrm{KgBB}$ & $47,78 \pm 2,51^{*}$ \\
EEDK $300 \mathrm{mg} / \mathrm{KgBB}$ & $47,58 \pm 4,70^{\star}$ \\
\hline
\end{tabular}

Keterangan:

* = Berbeda bermakna $(p<0,05)$ terhadap kontrol positif dengan uji Tukey
Tabel 4. menunjukkan efek dari ekstrak etanol daun kerehau terhadap kadar MDA pada model hewan mencit yang diinduksi Aloksan bahwa kelompok kontrol positif memiliki rata rata kadar MDA yang lebih tinggi dibandingkan dengan kelompok mencit lainnya. Setelah dilakukan pengukuran kadar 
MDA pada kelompok kontrol negatif, positif, kelompok pembanding, dosis uji EEDK 75 $\mathrm{mg} / \mathrm{KgBB}, 150 \mathrm{mg} / \mathrm{KgBB}$, dan $300 \mathrm{mg} / \mathrm{KgBB}$ masing-masing memiliki rata rata kadar MDA sebesar $89,38 \mathrm{nmol} / \mathrm{mL} ; 47,58 \mathrm{nmol} / \mathrm{mL}$; $77,78 \mathrm{nmol} / \mathrm{mL} ; \quad 63,78 \quad \mathrm{nmol} / \mathrm{mL} ; \quad 83,98$ $\mathrm{nmol} / \mathrm{mL}$; dan $84,38 \mathrm{nmol} / \mathrm{mL}$.

Dalam tabel tersebut, terdapat perbedaan yang sangat signifikan $(p<0,05)$ jika dibandingkan dengan kontrol positif. Kelompok model hewan diabetes yang diberi terapi dengan ekstrak etanol daun kerehau pada tingkat dosis 75,150 , dan $300 \mathrm{mg} / \mathrm{KgBB}$ ini menunjukkan penurunan kadar MDA jika dibandingkan dengan kontrol positif. Terlebih pada kelompok diabetes yang diobati ekstrak etanol daun kerehau 150 dan $300 \mathrm{mg} / \mathrm{KgBB}$ menunjukkan perbedaan yang signifikan $(p<0,05)$ dibandingkan dengan kelompok diabetes yang tidak diobati.

Telah diketahui bahwa diabetes adalah penyakit yang sangat memperngaruhi pada perkembangan stress oksidatif, tetapi hiperlipidemia juga tidak kalah penting peran nya dalam produksi ROS yang berlebihan dan sistem pertahanan antioksidan yang berkurang yang mengarah pada oksidasi makromolekul seperti kerusakan lipid dan DNA. Penanda kerusakan lipid terjadi saat produksi spesies oksigen reaktif yang berlebihan contohnya hidrogen peroksida dan molekul oksigen yang memodulasi fungsi biologis semua biomolekul menjadi target lipid untuk beroksidasi sehingga menghasilkan Malondialdehid. Berhubungan dengan penelitian ini, ditunjukkan bahwa aloksan dapat menghasilkan peningkatan kadar Malondialdehid yang sangat signifikan jika dibandingkan dengan kelomopok kontrol negatif. Peningkatan kadar stress oksidatif pada mencit diabetes disebabkan karena autoksidasi glukosa, glikasi protein, peroksidasi lipid dan aktivitas enzim antioksidan yang rendah (Abdallah, 2017).

Pengobatan model hewan mencit diabetes dengan ekstrak etanol daun kerehau menunjukkan efek yang sangat baik. Ada perbedaan yang sangat signifikan dibanding dengan kelompok diabetes yang tidak diobati. Dosis ekstrak etanol daun kerehau yang paling efektif adalah $300 \mathrm{mg} / \mathrm{KgBB}$ dengan tingkat perbedaan bermakna yang paling besar $(p<0,05)$. Hal ini menunjukkan bahwa pengobatan model hewan mencit diabetes yang diinduksi aloksan dengan ekstrak etanol daun kerehau secara signifikan dapat mempengaruhi kadar malondialdehid. Daun kerehau memiliki aktivitas antioksidan in vitro yang kuat dengan bekerjasama dengan kandungan senyawa bioaktifnya. Daun kerehau mempunyai efek perbaikan peroksidasi lipid berhubungan dengan senyawa metabolit sekunder yang dikandungnya yaitu flavonoid. Flavonoid adalah agen yang paling menjanjikan untuk pengobatan penyakit yang berkaitan dengan stress oksidatif (Erwin, dkk 2015).

\section{SIMPULAN DAN SARAN}

\section{Kesimpulan}

Dari penelitian ini dapat disimpulkan bahwa ekstrak etanol daun kerehau memiliki kemampuan mempengaruhi kadar malondialdehid pada serum mencit dengan senyawa metabolit sekunder yang dikandung yaitu flavonoid. Dosis yang paling efektif yaitu dosis $150 \mathrm{mg} / \mathrm{KgBB}$.

\section{Saran}

Berdasarkan hasi penelitian disarankan untuk perlu diteliti lebih dalam lagi efek antidiabetes daun kerehau dalam mempengaruhi kadar malondialdehid mengingat masih sedikit sekali penelitian tentang antidiabetes daun kerehau dalam mempengaruhi kadar malondialdehid.

\section{Ucapan Terimaksiah :}

Kami tim peneliti mengucapkan terimakasih kepada Sekolah Tinggi Farmasi Bandung yang telah mendanai penelitian tersebut.

\section{DAFTAR PUSTAKA}

Abdallah, Inas Z.A., Ibrahim, S. Salem and NAyrouz A.S. Abd El-Salam. 2017. "Evaluation of Antidiabetic and Antioxidant Activity of Aegle marmelos L. Correa Fruit Extract in Diabetic Rats". The Egyptian Journal of Hospital Medicine 67 (2): 731-741. 
Dipiro, J, Robert L Talbert, Gary Yee, Gary Matzke, Barbara Wells, Dan L Michael Posey. 2011. Pharmacotherapy. New York: McgrawHill Publishing.

Erwin, Redda An Nisa, \& Daniel Daniel. 2015. "Phytochemical Test, Toxicity And Antioxidant Activity Leaves Kerehau (Callicarpa longifolia Lam.) With Dpph Method." Indonesia Chimica Acta 8 (1): 52-59.

International Diabetes Federation, 2017. IDF diabetes atlas. International Diabetes Federation, Brussels.

Kurniasari, Silvie, Ari Hepi Yanti, dan Tri Rima Setyawati. 2017. "Kadar Malondialdehyde Induk dan Struktur Morfologis Fetus Mencit (Mus musculus) yang Diperdengarkan Murottal dan Musik Rock pada Periode Gestasi" 6: 9.

Lenzen, S. 2008. "The Mechanisms of Alloxan- and Streptozotocin-Induced Diabetes." Diabetologia 51 (2): 216-26. https://doi.org/10.1007/s00125-007-0886-7.

Roglic, Gojka, dan World Health Organization, ed. 2016. Global Report on Diabetes. Geneva, Switzerland: World Health Organization.

Semiawan, Ferry, Islamudin Ahmad, \& Muhammad Amir Masruhim. T.T. "Aktivitas Antiinflamasi Ekstrak Daun Kerehau.” . . Vol 1 (1): 4 .

Susilawati, E, I. Ketut Adnyana, Dan Neng Fisheri. 2017. "Kajian Aktivitas Antidiabetes Dari Ekstrak Etanol Dan Fraksinya Dari Daun Singawalang (Petiveria alliacea L.)." Pharmacy 13 (02).

Susilawati, E, Widhya Aligita, \& I Ketut Adnyana. 2018. "Activity Of Karehau (Callicarpa Longifolia Lamk.) Leaves Ethanolic Extract As A Wound Healing." J. Pharm. Sci. 10: 5.

Tiwari, Brahm Kumar, Kanti Bhooshan Pandey, A. B. Abidi, dan Syed Ibrahim Rizvi. 2013. "Markers of Oxidative Stress during Diabetes Mellitus." Journal of Biomarkers
2013:

$1-8$. 